\title{
KESULITAN SISWA DALAM MENYELESAIKAN SOAL FISIKA PADA MATERI SUHU DAN KALOR DI KELAS X SMA AR-RISALAH LUBUKLINGGAU TAHUN PELAJARAN 2016/2017
}

\author{
Leo Charli ${ }^{1}$, Ahmad Amin ${ }^{2}$, Desi Agustina ${ }^{3}$ \\ STKIP-PGRI Lubuklinggau ${ }^{1,2,3}$ \\ leocharli@gmail.com ${ }^{1}$
}

\begin{abstract}
ABSTRAK
Tujuan penelitian ini adalah untuk mengetahui jenis kesulitan, faktor penyebab, dan memberikan solusi mengatasi terjadinya kesulitan dalam menyelesaikan soal fisika materi suhu dan kalor. Penelitian ini adalah penelitian deskriptif kualitatif, sampel sebanyak 30 siswa, diambil dengan teknik purposive sampling. Teknik pengumpulan data menggunakan tes, angket, dan wawancara. Hasil analisis data tes ditemukan proporsi kesulitan memahami soal yaitu sebesar $80,3 \%$, kesulitan menggunakan simbol sebesar 76,2\%, kesulitan menggunakan rumus sebesar $84 \%$, kesulitan menganalisis grafik sebesar $65 \%$ dan kesulitan hitungan sebesar $90 \%$. Berdasarkan hasil wawancara dan angket, faktor penyebab siswa mengalami kesulitan memahami soal adalah siswa tidak memahami maksud dan tujuan soal, kurangnya pemahaman siswa terhadap materi, siswa jarang mengulang materi yang sudah dipelajari dirumah dan siswa malas latihan mengerjakan soal. Penyebab kesulitan menggunakan simbol adalah siswa lupa dengan simbol fisika dan siswa mengingat simbol dengan cara menghafal bukan memahaminya. Penyebab kesulitan menggunakan, karena siswa tidak tertarik serta merasa rumit dengan soal yang terdapat rumus, siswa tidak menguasai konsep materi dengan baik. Penyebab kesulitan menganalisis grafik adalah siswa tidak memahami maksud grafik, siswa merasa rumit dan tidak tertarik dengan soal yang terdapat grafik. Penyebab kesulitan hitung adalah siswa kurang tertarik dengan soal hitungan, siswa tidak teliti dalam menghitung, siswa kesulitan melakukan operasi hitung, dan guru jarang memberikan soal yang bervariasi. Simpulan, permasalahan ini dapat diatasi dengan sering membaca buku referensi, lebih rajin mengerjakan sendiri tugas yang diberikan guru, lebih giat lagi latihan soal-soal fisika dirumah, lebih berkonsentrasi ketika menganalisis grafik dan tidak terburuburu, siswa harus sering latihan soal perhitungan supaya keterampilan menghitung dapat meningkat.
\end{abstract}

Kata Kunci: Analisis Kesulitan, Menyelesaikan Soal, Suhu dan Kalor

\section{ABSTRACT}

The purpose of this study was to determine the types of difficulties, the causative factors, and provide solutions to overcome the difficulties in solving physics problems with temperature and heat matter. This type of research is a qualitative descriptive study, a sample of 30 students, taken by purposive sampling technique. Data collection techniques using tests, questionnaires, and interviews. The results of the analysis of the test data found the proportion of difficulties in understanding the questions that is equal to $80.3 \%$, difficulty using symbols at 
$76.2 \%$, difficulty using the formula at 84\%, difficulty analyzing graphics at $65 \%$ and difficulty at counting at $90 \%$. Based on the results of interviews and questionnaires, the factors causing students to have difficulty understanding the questions are students not understanding the purpose and objectives of the questions, lack of student understanding of the material, students rarely repeat the material that has been learned at home and students are lazy to practice working on the problems. The cause of difficulty using symbols is students forget about physics symbols and students remember symbols by memorizing instead of understanding them. The cause of difficulty using, because students are not interested and feel complicated with the problems contained in the formula, students do not master the material concepts well. The cause of difficulties in analyzing graphs is that students do not understand the purpose of the graph, students feel complicated and are not interested in the problems contained in the graph. The reason for arithmetic difficulties is that students are not interested in counting problems, students are not careful in calculating, students have difficulty doing arithmetic operations, and teachers rarely give varied problems. Conclusion, this problem can be overcome by frequently reading reference books, more diligent in doing the assignments given by the teacher, more active practice of physics problems at home, more concentrated when analyzing graphs and not in a hurry, students must often practice calculation problems so that the skills counting can increase.

Keywords: Difficulty Analysis, Solving Problems, Temperature and Heat

\section{PENDAHULUAN}

Pendidikan merupakan tugas negara yang amat penting, setiap bangsa dan negara perlu mempersiapkan segala hal dalam menghadapi pengaruh perkembangan teknologi terhadap pendidikan untuk peningkatan kualitas pendidikan. Kualitas pendidikan sebagai salah satu pilar pengembangan sumber daya manusia (SDM), bermakna strategis bagi pembangunan nasional. Dengan meningkatnya kualitas pendidikan diharapkan akan menghasilkan Sumber Daya Manusia (SDM) yang berkemampuan unggul yaitu manusia yang beriman dan bertaqwa kepada Tuhan YME, berakhlak mulia, sehat, berilmu, cakap, kreatif dan mandiri sehingga mampu menghadapi kemajuan ilmu pengetahuan dan teknologi yang sedemikian pesat.

Untuk menghasilkan Sumber Daya Manusia (SDM) yang berkemampuan unggul tentunya diperlukan peningkatan dalam berbagai bidang. Sehubungan dengan hal tersebut, pendidikan formal merupakan salah satu wadah dalam membangun Sumber Daya Manusia (SDM). Pendidikan IPA (fisika) sebagai bagian dari pendidikan formal seharusnya ikut memberi kontribusi dalam membangun sumber daya manusia yang berkualitas unggul.

Fisika sebagai salah satu cabang dari Ilmu Pengetahuan Alam (IPA) merupakan objek mata pelajaran yang menarik dan lebih banyak memerlukan pemahaman dari pada penghafalan. Namun, kenyataannya siswa sering beranggapan bahwa fisika merupakan pelajaran yang sulit dan kurang menarik. 
Hal ini dikarenakan dalam mata pelajaran fisika banyak menggunakan rumus sehingga dalam menyelesaikan suatu masalah fisika mereka bingung untuk memilih rumus mana yang harus digunakan. Selain itu tidak sedikit pula siswa yang mengalami kesulitan dalam menerima materi yang diajarkan dan tidak dapat memahami konsep fisika dengan baik, serta lemahnya kemampuan siswa dalam perhitungan matematis. Hal ini menyebabkan siswa mengalami kesulitan dalam mengerjakan soal fisika yang diberikan.

Penyebab kesulitan siswa harus segera mendapat pemecahan yang tuntas. Pemecahan ini ditempuh dengan cara menganalisis akar permasalahan yang menjadi penyebab kesulitan siswa dalam mengerjakan soal. Selanjutnya, diupayakan alternatif pemecahannya, sehingga kesulitan yang sama tidak terulang lagi dan dapat meningkatkan kualitas hasil belajar siswa.

Tujuan penelitian ini adalah untuk mengetahui jenis kesulitan, faktor penyebab, dan memberikan solusi mengatasi terjadinya kesulitan dalam menyelesaikan soal fisika materi suhu dan kalor.

\section{METODE PENELITIAN}

Jenis penelitian ini adalah penelitian deskriptif kualitatif, yang mana yang dimaksud kualitatif adalah data yang disajikan dalam bentuk deskripsi yang berupa teks naratif, kata-kata, ungkapan, pendapat, gagasan yang dikumpulkan oleh peneliti dari beberapa sumber sesuai dengan teknik atau cara pengumpulan data. Sampel pada penelitian ini adalah kelas X SMA Ar-Risalah Lubuklinggau tahun pelajaran 2016/2017 yang berjumlah 30 siswa. Sampel dipilih dengan teknik purposive sampling.

Teknik pengumpulan data menggunakan tes, angket, dan wawancara. Berdasarkan data hasil uji coba tes tersebut peneliti menghitungvaliditas dan reliabilitas,. Angket dan wawancara digunakan untuk mengetahui faktor-faktor penyebab siswa mengalami kesulitan dalam menyelesaikan soal. Wawancara hanya dilakukan kepada 6 orang siswa yang dipilih dari kategori siswa kemampuan tinggi, kemampuan sedang dan kemampuan rendah.

Teknik Analisis data pada penelitian ini meliputi reduksi data. Dalam reduksi data peneliti menentukan siswa yang mengalami kesulitan pada masingmasing indikator tiap butir soal., menghitung proporsi kesulitan siswa dari data tes, menghitung tingkat pengaruh faktor penyebab dari data angket, menghitung persentase jawaban angket tiap butir pernyataan, dan mendeskripsikan hasil wawancara. Setelah peneliti melakukan reduksi data, peneliti menyajikan data yang sudah dianalisis, setelah itu peneliti menarik kesimpulan dari seluruh data yang sudah dikumpulkan.

Untuk menguji keabsahan data peneliti melakukan ujicredibility, transferability, dependability, dan confirmability.Untuk uji credibility dilakukan dengan menggunakan triangulasi teknik pengumpulan data. Triangulasi teknik untuk menguji kredibilitas data dilakukan dengan cara mengecek data kepada 
sumber yang sama dengan teknik yang berbeda (Sugiyono, 2009). Pada penelitian ini peneliti membandingkan data antara hasil tes, hasil angket, dan hasil wawancara yang sumber datanya adalah siswa kelas X SMA Ar-Risalah Lubuklinggau.

\section{HASIL DAN PEMBAHASAN}

Penelitian ini dilaksanakan pada tanggal 10 Mei sampai 19 Mei 2017 di SMA Ar-Risalah Lubuklinggau. Subjek penelitian ini adalah kelas X dengan jumlah 30 siswa. Penelitian ini menggambarkan bentuk-bentuk kesulitan yang dialami siswa dalam menyelesaikan soal-soal uraian fisika pada materi suhu dan kalor, menunjukkan faktor-faktor penyebab siswa mengalami kesulitan, dan memberikan solusi untuk mengatasi kesulitan tersebut. Data penelitian diperoleh melalui pemberian soal tes untuk mengetahui kesulitan yang dialami siswa, penyebaran angket dan wawancara bertujuan untuk mengetahui tanggapan dan respon siswa mengenai materi suhu dan kalor serta faktor-faktor penyebab siswa mengalami kesulitan memahami soal, kesulitan menggunakan simbol, kesulitan menggunakan rumus, kesulitan menganalisis grafik dan kesulitan hitungan.

Berdasarkan analisis perhitungan diperoleh proporsi kesulitan siswa dalam memahami soal suhu dan kalor untuk siswa berkemampuan tinggi sebesar 58,6\% dengan kriteria kesulitan tinggi, siswa berkemampuan sedang sebesar 85,7\% dengan kriteria kesulitan tinggi dan siswa berkemampuanrendah sebesar 96,7\% dengan kriteria kesulitan tinggi. Persentase kesulitan siswa dalam menggunakan simbol untuk siswa berkemampuan tinggi sebesar 48,6\% dengan kriteria kesulitan rendah, siswa berkemampuan sedang sebesar 82,2\% dengan kriteria kesulitan tinggi dan siswa berkemampuanrendah sebesar 97,8\% dengan kriteria kesulitan tinggi. Persentase kesulitan siswa dalam menggunakan rumus untuk siswa berkemampuan tinggi sebesar 69,8\% dengan kriteria kesulitan tinggi, siswa berkemampuansedang sebesar $84,4 \%$ dengan kriteria kesulitan tinggi dan siswa berkemampuanrendah sebesar 97,8\% dengan kriteria kesulitan tinggi. Persentase kesulitan dalam menganalisis grafik untuk siswa berkemampuan tinggi sebesar $25 \%$ dengan kriteria kesulitan rendah, siswa berkemampuan sedang sebesar $70 \%$ dengan kriteria kesulitan tinggi dan siswa berkemampuanrendah sebesar $100 \%$ dengan kriteria kesulitan tinggi. Persentase kesulitan dalam hitungan untuk siswa berkemampuan tinggi sebesar $81,3 \%$ dengan kriteria kesulitan tinggi, siswa berkemampuansedang sebesar 91,2\% dengan kriteria kesulitan tinggi dan siswa berkemampuanrendah sebesar 97,8\% dengan kriteria kesulitan tinggi.

Kesulitan memahami soal yaitu kesulitan yang dialami siswa dalam menentukan apa yang diketahui dan apa yang ditanyakan dalam soal. Pada soal nomor satu siswa kesulitan dalam menentukan variabel yang diketahui dari termometer celcius karena tidak dituliskan secara jelas didalam soal sehingga untuk menjawab soal nomor 1 ini pemahaman yang baik terhadap konsep suhu dan kalor sangat diperlukan, hampir seluruh siswa mengalami kesulitan pada 
tahap ini. Pada soal nomor dua, kategori siswa yang mengalami kesulitan dalam memahami soal tergolong paling sedikit, siswa yang dianggap mengalami kesulitan memahami soal pada soal ini yaitu siswa yang langsung menuliskan rumus namun tidak menuliskan variabel diketahui dan ditanya. Pada soal nomor tiga, sebagian siswa mengalami kesulitan ketika menentukan suhu awal dan suhu akhir, terbukti dari lembar jawaban yang ditulis siswa tidak sedikit siswa yang menulis $\mathrm{T}_{1}=0$ dan $\mathrm{T}_{2}=-12$ padahal yang benar kebalikannya. Pada soal nomor empat lebih dari sebagian siswa mengalami kesulitan dalam memahami soal, terlihat dari jawaban siswa yang hanya beberapa menuliskan lengkap variabel yang diketahui dan ditanya. Pada soal nomor lima, juga banyak siswa yang mengalami kesulitan yang ditandai dengan tidak adanya siswa yang menuliskan variabel $\beta$ pada apa saja yang dikatahui dalam soal serta hanya sedikit siswa yang mampu menentukan variabel yang ditanya pada soal tersebut. Untuk soal nomor enam dan nomor tujuh, kebanyakan siswa bingung dalam menentukan apa yang ditanyakan dalam soal. Kemudian untuk soal nomor 8 dan 9, banyak siswa mengalami kesulitan dalam menentukan variabel yang diketahui pada soal, karena memang dalam soal ini variabel yang diketahui diletakkan secara tersembunyi, sehingga untuk menjawab soal ini pemahaman yang baik mengenai materi suhu dan kalor sangat dibutuhkan.

Kesulitan menggunakan simbol fisika yaitu kesulitan yang dialami siswa dalam menuliskan simbol-simbol yang digunakan untuk fisika. Pada indikator kesulitan simbol, untuk tiap soalnya tergolong banyak siswa yang mengalami kesulitan, namun persentase kesulitan yang paling rendah yaitu terletak pada soal nomor dua. Siswa yang tergolong mengalami kesulitan dalam menggunakan simbol yaitu siswa yang menuliskan nama besaran fisika bukan menuliskan simbol fisika.

Indikator yang ketiga yaitu kesulitan dalam menggunakan rumus,. Kesulitan ini merupakan kesulitan yang dialami siswa ketika menentukan persamaan atau rumus yang akan digunakan serta kesulitan dalam membolakbalikan rumus. Persentase yang paling tinggi untuk indikator ini yaitu terjadi pada soal nomor 1, 4, 5, 8 dan 9 dengan persentase sebesar $100 \%$ yang artinya tidak ada satupun siswa yang mampu menentukan rumus yang digunakan pada soal tersebut. Sedangkan persentase yang paling rendah yaitu terjadi pada soal nomor tiga.

Indikator yang keempat yaitu kesulitan dalam menganalisis grafik. Kesulitan menganalisis grafik yaitu kesulitan yang dialami siswa ketika membaca grafik atau gambar. Pada penelitian ini kesulitan siswa dalam menganalisis grafik dilihat dari hasil jawaban siswa pada soal nomor 6 dan 7. Untuk indikator ini lebih dari separuh siswa yang mengalami kesulitan baik pada soal nomor 6 maupun soal nomor 7. Kesulitan siswa pada indikator ini berkaitan dengan indikator pemahaman soal dan indikator menggunakan rumus, karena siswa yang tidak mampu menentukan variabel yang ditanya serta tidak mampu dalam menentukan 
rumus yang digunakan, berarti siswa tersebut tidak mampu dalam menganalisis atau membaca grafik.

Indikator yang kelima yaitu kesulitan dalam hitungan. Kesulitan hitungan yaitu kesulitan yang dialami siswa terkait perhitungan untuk menyelesaikan soal. Pada indikator ini, siswa yang dikatakan tidak mengalami kesulitan jika siswa tersebut benar dalam melakukan perhitungan. Namun karena kenyataan yang ada banyak siswa yang tidak mampu menjawab soal sampai ketahap ini, sehingga siswa yang tergolong menjawab soal dengan kategori tersebut dianggap mengalami kesulitan dalam hitungan. Sehingga pada tiap soal siswa yang mengalami kesulitan dalam hitungan tergolong tinggi.

Menurut Andriani (2016) kesulitan siswa dalam menyelesaikan soal pada tahap pemahaman soal disebabkan karena siswa tidak memahami soal dan tidak dapat menterjemahkan/mengubah soal kedalam bentuk rumus atau bentuk matematika sehingga tidak dapat menulis apa yang diketahui dan ditanyakan. Pada penelitian ini faktor yang menyebabkan siswa mengalami kesulitan menyelesaikan soal pada tahap pemahaman soal yaitu siswa tidak memahami maksud dan tujuan dari soal, siswa tidak memiliki tingkat pemahaman yang baik terhadap materi suhu dan kalor, siswa menganggap bahwa materi suhu dan kalor itu sulit, sebagian siswa merasa sulit dalam mencerna bahasa yang digunakan dalam soal, siswa kurang teliti dalam membaca soal karena tidak konsentrasi.

Faktor yang menyebabkan siswa mengalami kesulitan menyelesaikan soal yang berhubungan dengan menggunakan simbol pada penelitian ini yaitu siswa tidak memahami simbol fisika, siswa tidak mudah dalam mengingat simbol, siswa mengingat simbol dengan cara yang tidak efektif yaitu dengan cara menghafal. Padahal terdapat cara yang lebih baik dalam mengingat simbol yaitu dengan cara memahami maksud dari simbol itu sendiri, namun cara ini jarang sekali diterapkan oleh siswa karena sebagian besar siswa malas untuk mempelajari materi fisika di rumah.

Faktor yang menyebabkan siswa mengalami kesulitan menyelesaikan soal yang berhubungan dengan menggunakan rumus pada penelitian ini yaitu siswa tidak menguasai konsep materi dengan baik sehingga siswa tidak mengetahui rumus yang harus digunakan, siswa mengingat rumus fisika dengan cara menghafal bukan dengan cara memahami konsep, siswa jarang latihan soal-soal fisika yang menggunakan rumus di rumah, siswa tidak tertarik belajar menggunakan rumus, siswa merasa rumit mengerjakan soal yang menggunakan rumus, siswa tidak memahami cara membolak-balikan rumus.

Faktor yang menyebabkan siswa mengalami kesulitan menyelesaikan soal yang berhubungan dengan menganalisis atau membaca grafik pada penelitian ini yaitu siswa tidak tertarik mengerjakan soal yang berhubungan dengan grafik, siswa tidak memahami maksud grafik, siswa sering terkecoh dengan grafik yang ada pada soal, guru jarang memberikan latihan soal yang menggunakan grafik. Hal ini sesuai dengan pendapat Mustain (2015) yang menyatakan bahwa siswa 
mengalami kesulitan dalam membaca, memahami dan membuat grafik dan data disebabkan karena siswa kurang mendapatkan pengetahuan, penjelasan dan kegiatan praktis dari guru berkenaan dengan penyajian grafik dan data. Selain itu Azizah (2015) juga menemukan permasalahan yang sama pada siswa SMA, dimana dalam mengerjakan soal grafik siswa tersebut masih salah dalam membaca dan mengartikan soal grafik.

Yulfiana (2015) kesulitan yang dilakukan siswa dalam operasi hitung disebabkan siswa tidak terampil dalam melakukan perhitungan, siswa belum paham terhadap bentuk satuan dari volume dan luas, dan siswa terburu-buru dalam menyelesaikan soal sehingga tidak teliti saat menghitung. Faktor yang menyebabkan siswa mengalami kesulitan dalam melakukan operasi hitung pada penelitian ini yaitu siswa kurang tertarik dengan soal yang menggunakan operasi hitung, siswa tidak teliti dalam melakukan perhitungan, siswa merasa rumit dalam menjawab soal hitungan, kemampuan berhitung siswa rendah sehingga dalam mengerjakan soal hitungan siswa mengalami kesulitan, siswa kesulitan menghitung bilangan berpangkat, mengitung bilangan yang banyak terdapat banyak nominal, serta kesulitan menghitung bilangan berkoma. Siswa terburuburu dalam melakukan perhitungan karena dikejar waktu, metode yang digunakan guru tidak membuat siswa bersemangat untuk mengikuti pelajaran siswa tidak mengulang kembali materi di rumah kecuali saat ada tugas dan ketika mau ulangan, siswa tidak memperhatikan guru menjelaskan materi, siswa tidak belajar dengan buku fisika yang berbeda-beda, kurangnya motivasi yang diberikan guru saat mengawali pembelajaran.

Setiandari (2013) solusi untuk mengatasi kesulitan siswa dalam mengerjakan soal-soal fisika yaitu (a) metode mengajar guru dirubah ke metode yang lebih efektif, misalnya diskusi informasi (b) membuat peta konsep agar materi yang diberikan lebih terarah (c) dalam penjelasan materi guru harus benarbenar dapat menjelaskan materi dasar sampai aplikasinya (d) dalam pemberian PR sebaiknya guru menyuruh siswa mengumpulkan PR sehari sebelum pelajaran fisika agar guru mengetahui siswa mengerjakan sendiri atau tidak. Guru juga dapat mengetahui bagian mana siswa mengalami kesulitan, sehingga guru dapat menjelaskannya ketika pembelajaran Fisika.

Solusi untuk faktor penyebab kesulitan siswa dalam memahami soal pada penelitian ini yaitu siswa dituntut untuk giat belajar agar pemahaman konsep terhadap materi suhu dan kalor siswa lebih luas dan mendalam, sehingga membuat siswa lebih mudah memahami maksud dan tujuan soal. Kemudian, siswa juga harus pintar mengatur waktu agar lebih sering latihan soal di rumah guna meningkatkan pemahaman siswa terhadap soal, siswa harus lebih berkonsentrasi dalam belajar serta lebih aktif dalam kegiatan pembelajaran, serta siswa harus teliti dalam membaca soal.

Solusi untuk faktor penyebab kesulitan siswa pada indikator menggunakan simbol pada penelitian ini yaitu siswa harus memahami maksud dari simbol fisika, 
artinya disini siswa harus paham betul maksud dari masing-masing simbol fisika bukan hanya tahu simbolnya saja. Alternatif yang dapat digunakan siswa guna mengurangi tingkat kesulitan terhadap penggunaan simbol yaitu siswa harus belajar mengingat simbol fisika bukan dengan cara menghafal tetapi dengan cara memahaminya. Selain itu siswa juga bisa mengingat simbol dengan cara rajin latihan mengerjakan soal-soal fisika dirumah.

Selanjutnya alternatif yang dapat digunakan untuk mengatasi faktor penyebab siswa mengalami kesulitan dalam menyelesaikan soal pada indikator yang ketiga yaitu indikator kesulitan dalam menggunakan rumus, solusi yang paling utama untuk indikator ini ialah siswa harus menumbuhkan rasa ketertarikannya terhadap soal yang menggunakan rumus. Kemudian siswa harus rajin belajar agar menguasai konsep materi dengan baik sehingga siswa mampu menentukan rumus yang digunakan dalam soal, siswa harus mencoba mengingat rumus dengan cara memahami konsepnya bukan dengan cara meghafal, siswa harus sering latihan soal-soal fisika yang menggunakan rumus dirumah, siswa juga dituntut untuk belajar membolak-balikkan rumus.

Solusi untuk faktor penyebab kesulitan siswa dalam menganalisis grafik pada penelitian ini yaitu siswa harus menumbuhkan rasa ketertarikannya terhadap soal yang menggunakan grafik, guru lebih sering memberikan soal yang menggunakan grafik, siswa lebih sering latihan mengerjakan soal yang menggunakan grafik guna memperkuat pemahaman terhadap konsep yang ada pada grafik sehingga siswa tidak mudah terkecoh ketika menjawab soal yang menggunakan grafik. Khusus pemahaman terhadap grafik pada materi suhu dan kalor siswa harus mampu memahami letak titik beku, titik cair, titik didih dan titik saat zat mengalami penguapan di dalam grafik agar ketika diminta untuk menentukan rumus dari grafik siswa dapat menentukannya.

Solusi untuk faktor penyebab kesulitan siswa dalam hitungan pada penelitian ini yaitu siswa harus menumbuhkan rasa ketertarikannya terhadap soal yang menggunakan operasi hitung, siswa harus teliti dalam melakukan perhitungan, siswa harus meningkatkan kemampuan berhitung mereka dengan cara lebih sering latihan mengerjakan soal hitungan, seperti belajar menghitung bilangan berpangkat, mengitung bilangan yang terdapat banyak nominal serta menghitung bilangan berkoma, guru harus menggunakan metode yang lebih efektif agar siswa semangat dalam mengikuti pembelajaran, siswa harus selalu memperhatikan guru ketika menjelaskan materi, guru harus mengawali pembelajaran dengan selalu memberikan motivasi.

\section{SIMPULAN}

Proporsi kesulitan siswa dalam menyelesaikan soal fisika materi suhu dan kalor untuk indikator kesulitan memahami soal yaitu sebesar 80,3\% dengan kriteria kesulitan tinggi, indikator kesulitan menggunakan simbol sebesar 76,2\% dengan kriteria kesulitan tinggi, indikator kesulitan menggunakan rumus sebesar 
$84 \%$ dengan kriteria kesulitan tinggi, indikator kesulitan menganalisis grafik sebesar $65 \%$ dengan kriteria kesulitan tinggi dan indikator kesulitan hitungan sebesar 90,1\% dengan kriteria kesulitan tinggi.

Faktor-faktor penyebab siswa melakukan kesulitan dalam menyelesaikan soal fisika yaitu siswa tidak paham terhadap materi suhu dan kalor, siswa menganggap materi suhu dan kalor sulit, siswa sulit mencerna bahasa yang digunakan dalam soal, siswa merasa rumit mengerjakan soal yang menggunakan rumus, siswa tidak memahami cara membolak-balikan rumus, siswa tidak memahami maksud grafik, siswa merasa rumit dalam menjawab soal hitungan, kemampuan berhitung siswa rendah, siswa kesulitan menghitung bilangan berpangkat, kesulitan menghitung bilangan yang banyak terdapat nominal, serta kesulitan menghitung bilangan berkoma, siswa terburu-buru dalam melakukan perhitungan.

Solusi untuk mengatasi terjadinya kesulitan-kesulitan dalam menyelesaikan soal yaitu siswa seharusnya banyak membaca buku referensi yang dapat meningkatkan pemahaman, siswa sebaiknya lebih rajin mengerjakan sendiri tugas yang diberikan guru, siswa harus lebih giat lagi latihan soal-soal fisika dirumah, siswa harus rajin belajar mengerjakan soal yang terdapat grafik, berkonsentrasi ketika menganalisis grafik dan tidak terburu-buru, siswa harus sering latihan soal perhitungan supaya keterampilan menghitung dapat meningkat.

\section{DAFTAR PUSTAKA}

Andriyani, Ni, L., Y. (2015). Analisis Kesulitan Siswa Dalam Menyelesaikan Soal Gerak Lurus. Jurnal Pendidikan Fisika Tadulako (JPFT). 4 (3), 36-41.

Azizah, R. (2015). Kesulitan Pemecahan Masalah Fisika Pada Siswa SMA. Jurnal Pendidikan Fisika dan Aflikasinya (JPFA). 5 (2). 44-50.

Mustain, L. (2015). Kemampuan Membaca Dan Interpretasi Grafik Dan Data: Studi Kasus Pada Siswa Kelas 8 SMPN. Scientiae Educatia. 5 (2), 1-11.

Setiandari, D. (2013). Analisis Kesulitan Siswa Dalam Mengerjakan Soal-Soal Fisika Materi Gerak Lurus Kelas VII Semester 2 SMP Tahun Ajaran 2011/2012. Skripsi tidak diterbitkan. Surakarta: S1 Program Pendidikan Fisika Universitas Sebelas Maret.

Sugiyono. (2009). Memahami Penelitian Kualitatif. Bandung: Alfabeta.

Yulfiana. (2015). Analisis Kesulitan Siswa Dalam Menyelesaikan Soal-Soal Volume Bangun Ruang Sisi Lengkung Pada Siswa Kelas Ix Smp Muhammadiyah 9 Ngemplak Tahun Ajaran 2015/2016. Skripsi tidak diterbitkan. Surakarta: S1Program Pendidikan Matematika Universitas Muhammadiyah 